"stacked" frequencies of older age classes, such methods have only limited value. An approach utilising computer graphics in simulations of the growth and survivorship schedules through the life history of a species showing seasonal recruitment has been found to provide a powerful tool in developing likely hypotheses of age structure of deep-sea brittle stars, such as Ophiomusium lymani.

The development of such models is much aided by the discovering of skeletal markers in the form of annual banding in certain species. In the deep-sea echinoid Echinus affinis growth zones are evident in the plates of the test and in the jaw ossicles. Banding is present in the plates of even small, pre-reproductive stages. It is likely that such annual banding is the result of a seasonally varying growth rate as a result of the marked seasonal cycle in availability of a fallout of fast-sinking phytodetritus from the surface on which this urchin probably feeds. Counts of growth banding have provided a growth curve that, although indicating a slower growth and longer life span than inshore relatives, is not exceptional among certain other benthic species living in shallow-water.

Preliminary studies of growth rings on the shells of small, seasonally-breeding bivalves that are among the most abundant species living on the bottom, have suggested growth rates and generation times similar to those estimated from inshore relatives.

Overall, the analysis of population dynamics of deep-sea organisms from the time-series sampling offers little support for the notion of growth rates being generally low and life spans being exceptionally attenuated. It would seem reasonable to expect a mix of life-history strategies similar to that found in shallow water, and encompassing both slow and fast rates of population turnover, to occur in the deep sea.

\title{
Shelf break faunas on the eastern margin of the Rockall Trough and Faeroe-Shetland Channel
}

\section{J. B. Wilson and J. M. Desmond}

Institute of Oceanographic Sciences, Brook Road, Wormley, Godalming, Surrey GU8 5UB, U.K.

Investigations into the sediments and shell-bearing faunas on the upper continental slope, the shelf break and the outer parts of the continental shelf on the eastern margins of the Rockall Trough and Faeroe-Shetland Channel suggest that a distinctive faunal association can be recognised which is restricted to the shelf break.

The distributions of some thirty-seven species of molluscs, echinoderms, coelenterates (mostly corals) and crustaceans (barnacles) have suggested that the association contains three groups of species: shelf species which range over the shelf break and onto the upper slope, continental slope species whose upper depth limit reaches the shelf break and the outer parts of the continental shelf and a third group of species which is largely restricted to the shelf break. 
Within the third group are several species including the bivalves Bentharca nodulosa (Müller), Limopsis aurita (Brocchi) and the gastropod Solariella amabilis (Jeffreys). Their presence in this region may be temperature controlled, as they are shelf species in northern Norway whereas in the Bay of Biscay they are found on the middle of the continental slope. Other species present at the shelf break are perhaps near the southern limit of their range and are restricted to the shelf break on the eastern margin of the Faeroe-Shetland Channel. Species in this group include the bivalve Chlamys sulcata (Müller) and the gastropod Troschelia berniciencis (King). A number of rare species are present at the shelf break. These include the gastropods Metzgeria gagei Bouchet and Volutomitra groenlandica (Beck) and the coral Stenocyathus vermiformis (Pourtalès). The records of Stenocyathus and Volutomitra are the first live records in U.K. waters. A feature of the shelf break in this region is the extensive development of iceberg plough marks. Samples dredged from the shelf break have a very distinctive appearance and consist of poorly sorted collections of small boulders, cobbles, pebbles, gravel and sand. Observations of the shelf break and upper slope using the Mark III Television and Camera Sledge confirm the highly variable nature of the sediments present.

The regular echinoid Cidaris cidaris (Linnaeus) and the bivalve Astarte sulcata (da Costa) are very common in these poorly sorted gravels and their presence together is very characteristic of the shelf break. In some parts the poorly sorted gravels give way to more sandy sediments which support species such as the gastropods Typhlomangelia nivalis (Loven) and Cylichna alba (Brown).

Dead shells of species living in the area during the period of low sea level preceding the Flandrian transgression such as the bivalve Chlamys islandicus (Müller) and less commonly Mya truncata (Linnaeus) are also present.

\title{
Aspects of the zoogeography of some benthic animals in the Rockall Trough
}

\author{
G. L. J. Paterson
}

Department of Zoology, British Museum (Natural History), Cromwell Road, London SW7 5BD, U.K.

Distributions of certain benthic species in the Rockall Trough are compared to other regions of the Northeast Atlantic. A numerical cladistic package has been applied to classify the distributions of deep-sea (>500 $\mathrm{m}$ depth) brittle star fauna. Rockall is compared with the Labrador and Southwest Iceland basins, the Iceland Basin, the Bay of Biscay and the Canary region including the Azores, Madeira and N. Africa. Figure $1 \mathrm{~A}$ indicates that the Rockall Trough fauna has a greater affinity to the Biscay and Canary regions than the other two northerly basins. These results are consistent with an hypothesis of an impoverishment of the northern basins, possibly related to the effects of the last Ice Age. 